\title{
Identification and Characterization of the Fibrinolytic Enzymes producing Bacterium Strain (Isolate KLG 55) from the Soil Waste
}

\author{
S.M. Gopinath* and K. Lingappa \\ Department of Microbiology, Gulbarga University, Gulbarga, Karnataka, India \\ *Corresponding author email id:
}

\section{A B S T R A C T}

\section{Keywords}

Fibrinolytic activity, purification, Sephadex G-50 gel permeation chromatography and DEAE Sephadex A-50 anion exchange chromatography.

\section{Article Info}

Accepted:

28 June 2016

Available Online:

10 July 2016
The present work was conducted to characterize the fibrinolytic enzyme produced by the strains of the isolates of Bacillus cereus sp. obtained from the soil waste. The isolated organism was cultured in the sterile media at $37^{\circ} \mathrm{C}$ for $24 \mathrm{hrs}$. The selected isolates were subjected to fibrinolytic activitiy. The fibrinolytic activity of isolates KLG 55 was higher and it was subjected for biochemical studies. Based on the study, isolate was designated as Bacillus cereus KLG 55. Further it was subjected to three step purification involving ammonium sulphate precipitation, Sephadex G-50 gel permeation chromatography and DEAE Sephadex A-50 anion exchange chromatography. After the purification processes, the molecular weight of fibrinolytic protease enzyme is $31 \mathrm{kDa}$.

\section{Introduction}

With the increasing industrial application of fibrinolytic proteases, the search for promising strains of fibrinolytic proteases producers has became a continuous process. Proper identification and characterization of microorganisms is very important because it expands the scope for exploitation of industrially important products. Various morphological, cultural and biochemical characteristics of the isolated organisms were compared with the descriptions of the numerous bacterial species such as Bergey's Manual of Determinative Bacteriology (Buchanan et al., 1974), Bergey's Manual of Systemic Bacteriology (Williams et al., 1989), Bergey's Manual of Systemic
Bacteriology (Sneath et al., 1986), Biological and Microbiological abstracts and all other relevant journals (Fundagul et al., 2009; Mousumi Banerjee et al., 2011; Vyletelova et al., 2002).

To isolate the potent fibrinolytic protease producing bactreria, brick red sticky soil sample was collected from various places in and around Bangalore, Karnataka, India.The soil samples were selected based on the varying characterisitics such as organic matter, particle size, colour of soil and geographical distribution. The samples were stored in sterile condition. 
The isolates were initially screened for their proteolytic activities such as caseinolytic, gelatinolytic and fibrinolytic activities. Shake flask fermentation was considered for the production of fibrinolytic protease.

The promising isolate KLG 55 was subjected to taxonomic studies. The taxonomic properties were investigated for the characterization of the isolate KLG 55.

\section{Materials and Methods}

In the present work, strain that produces fibrinolytic enzyme (GD55) was isolated from the soil sample collected from different geographical locations in and around Bangalore, India.

\section{Microorganism and Inoculum preparation}

The slants were inoculated from the stock cultures and incubated at $37^{\circ} \mathrm{C}$ for $1-3$ days to get maximum sporulation. Spore suspension was prepared by transferring a loopful of spores from these slants into sterile distilled water and shaking thoroughly.

Stock cultures were maintained in nutrient broth medium with $70 \%$ glycerol, cultures were preserved at $-20^{\circ} \mathrm{C}$ (Richard et al., 2009). The inoculum was prepared by transferring a loopful of the isolate to $100 \mathrm{ml}$ of sterile nutrient broth stock medium, then incubated it overnight at $37^{\circ} \mathrm{C}$ on a rotary shaker with 200rpm. A stock suspension was prepared and adjusted to $7 \times 10^{3}$ cells $\mathrm{ml}^{-1}$

\section{Identification of the isolate KLG 55}

The morphological characteristics, physiological properties based on the effect of the temperature, $\mathrm{pH}$, growth of isolate using different concentration of sodium chloride and biochemical properties, carbon source utilization pattern, growth in the presence of various nitrogen sources and resistance or sensitivity to various antibiotics were analysed for the selected isolate.

\section{Production of Fibrinolytic protease}

The medium used for the production of fibrinolytic protease was composed of $0.2 \%$ fibrin, $1 \%$ fructose, $1 \%$ peptone, $0.2 \%$ $\mathrm{KH}_{2} \mathrm{PO}_{4}, 0.04 \% \mathrm{CaCl}_{2}, 0.05 \% \mathrm{NH}_{4} \mathrm{NO}_{3}$ and $0.02 \% \mathrm{MgSO}_{4}$. The $\mathrm{pH}$ of the medium was adjusted to 8 using $\mathrm{HCl} / \mathrm{NaOH}$. One percent $(\mathrm{v} / \mathrm{v})$ of $24 \mathrm{~h}$ old inoculum suspension was transferred to $100 \mathrm{ml}$ of growth medium in $250 \mathrm{ml}$ Erlenmeyer flasks. These flasks were then placed in the rotary incubator shaker rotating at $200 \mathrm{rpm}$ for $24 \mathrm{~h}$ at $37^{\circ} \mathrm{C}$. The broth was then centrifuged at $10,000 \mathrm{rpm}$ for $10 \mathrm{~min}$ at $4^{\circ} \mathrm{C}$ and the clear supernatant (crude enzyme)was used for the estimation of fibrinolytic protease (Greenberg 1957).

\section{Enzyme purification}

\section{Ammonium sulfate fractionation and Dialysis}

Supernatant containing crude enzyme obtained after centrifugation was subjected to ammonium sulfate fractionation, at different concentrations ranging from 30$80 \%$ saturation (Olajuyigbe et al., 2005). The precipitates obtained were suspended in $2 \mathrm{ml}$ of cold saline. It was then subjected for fibrinolytic activity and total protein content. To obtain complete precipitation of the crude enzyme, the crude enzyme was subjected to ammonium sulfate precipitation at $70 \%$ saturation at $4^{\circ} \mathrm{C}$ by subjecting it to centrifugation at $10000 \mathrm{rpm}$ for $15 \mathrm{~min}$, It was again suspended in $100 \mathrm{ml}$ of cold saline solution and dialyzed (Balaraman et al., 2007 ) in cold against 1 litre of $20 \mathrm{mM}$ Tris- 
HCL buffer at $\mathrm{pH} 8$ for $24 \mathrm{~h}$. After dialysis, the solution was centrifuged and supernatant obtained was next subjected to gel filtration chromatography.

\section{Gel Filtration Chromatography}

The sample obtained from ammonium fractionatin was centrifuged at $8000 \mathrm{~g}$ for $15 \mathrm{~min}, \quad$ and supernatant was chromatographed on a Sephadex G-50 Column (Jo et al., 2011). The sample was first loaded onto a column of Sephadex G$50(120 \mathrm{~cm} \times 1.0 \mathrm{~cm})$ and it was then followed by DEAE Sephadex A-50 column $(24 \mathrm{~cm} \times 2.0 \mathrm{~cm})$, both the columns were equilibrated with $10 \mathrm{mM}$ Tris-Hcl buffer at pH 8 (Peng et al., 2003). The column was eluted at a flow rate of $1 \mathrm{ml} / 6 \mathrm{~min}$ with a discontinuous gradient ranging from $0.2 \mathrm{M}$ to $1.0 \mathrm{M}$ of $\mathrm{NaCl}$ dissolved in same buffer.

The fractions collected were determined for its total protein concentration and fibrinolytic activity. The active fractions with high fibrinolytic activity were dialyzed and used for further studies.

\section{Sodium dodecyl sulfate polyacrylamide gel electrophoresis (SDS-PAGE) analysis}

The active fractions showing the highest specific activity were pooled, dialyzed, lyophilized and then subjected to Sodium Dodecylsulfate Polyacrylamide Gel Electrophoresis (SDS-PAGE). SDS-PAGE was carried out using a 5\% stacking gel and a $12 \%$ polyacrylamide resolving gel according to the method of Laemmli (Laemmli et al., 1970). To run the SDS gel, the electrophoresis buffer containing $25 \mathrm{mM}$ Tris, and $250 \mathrm{mM}$ glycine (Electrophoresis grade) at $\mathrm{pH} 8.8$ was used. The SDS was added at a concentration of $0.1 \%$ to the electrophoresis buffer. A molecular weight marker (Bio-Rad) was used as reference proteins, crude broth and fraction were dissolved in sample buffer containing $0.2 \mathrm{M}$ Tris HC1 (pH 6.8), 10\% SDS, 20\% glycerol, $10 \mathrm{mM}$ 3-mercaptoethanol and $0.05 \%$ bromophenol blue as the tracking dye and boiled for $10 \mathrm{~min}$ to determine the protein. The treated samples were loaded in the wells of the slab gel and electrophoresis was continued till the tracking dye reached the lower end of the gel. After the complete run, the gel was soaked overnight (about 16h) in a fixative solution containing $50 \%(\mathrm{v} / \mathrm{v})$ methanol and $12 \%$ acetic acid. After taking out the gel from the fixative solution, it was stained for one hour with $0.25 \%$ Coomassie Brilliant Blue R-250 in methanol/ water/ acetic acid (50: 40: 10) and the gel was finally destained in a destaining solution containing water/ acetic acid/ methanol (87.5: $7.5: 5)$.

\section{Fibrinolytic Protease Assay}

Fibrinolytic protease activity was assessed by the modified procedure of Greenberg (1957) using $2 \%$ bovine fibrin in $0.05 \mathrm{mM}$ phosphate buffer ( $\mathrm{pH}$ 8). $0.5 \mathrm{ml}$ fibrin solution with an equal volume of diluted enzyme solution was incubated for $10 \mathrm{~min}$ at $37^{\circ} \mathrm{C}$. The reaction was stopped by the addition of $10 \%$ cold Tri Chloroacetic Acid (TCA). The mixture was centrifuged at 3,000rpm for $10 \mathrm{~min}$ and to the supernatant $5 \mathrm{ml}$ of $0.44 \mathrm{M} \mathrm{Na}_{2} \mathrm{CO}_{3}$ was added, followed by the addition of $1 \mathrm{ml}$ of diluted Folin ciocalteau reagent. The mixture was incubated for $30 \mathrm{~min}$ at $37^{\circ} \mathrm{C}$, the sample develops color change, and the intensity of colour change will be measured at $660 \mathrm{~nm}$ using Shimadzu UV-1700 spectrophotometer against the blank solution containing fibrin substrate. Tyrosine is used as the reference standard.Total protein concentration was determined using Lowry's method (Lowry et al., 1951). 


\section{Characterization of purified enzyme}

\section{Effect of pH on Enzyme activity}

The optimal $\mathrm{pH}$ of the enzyme was determined between $\mathrm{pH}$ 3.0-12.0 was examined by incubating the enzyme solution for $30 \mathrm{~min}$ at $37^{\circ} \mathrm{C}$ using the following buffer systems: $10 \mathrm{mM}$ citric acid buffer, $0.05 \mathrm{M}$ sodium phosphate buffer, $0.05 \mathrm{M}$ Tris- $\mathrm{HCl}$, $0.05 \mathrm{M}$ glycine- $\mathrm{NaOH}, \quad 0.1 \mathrm{M}$ sodium phosphate buffer, $0.05 \mathrm{M}$ hydroxyl-chlorite buffer respectively. All experiments were done in triplicates.

\section{Effect of Temperature on Enzyme activity}

The activity of the purified enzyme was determined by incubating the reaction mixture at different temperatures $(10,20$, $30,37,40,50,60$ and $70^{\circ} \mathrm{C}$ ) for $30 \mathrm{~min}$. Stability of fibrinolytic protease was investigated by measuring the residual activity after incubating the enzyme solution at $20-80^{\circ} \mathrm{C}$ for $30 \mathrm{~min}$ in $20 \mathrm{mM}$ phosphate buffer at $\mathrm{pH} 8$. All experiments were done in triplicates.

\section{Hydrolysis of protein substrates}

Protease activity with various protein substrates such as Bovine Serum Albumin (BSA), casein, egg albumin and gelatine was assayed by mixing $10 \mu 1$ of the purified enzyme and $200 \mu$ l of assay buffer containing the $2 \mathrm{mg} / \mathrm{ml}$ of protein substrates. After incubation at $37^{\circ} \mathrm{C}$ for $30 \mathrm{~min}$, the reaction was stopped by adding $200 \mu \mathrm{l}$ of $10 \%$ TCA (w/v) and allowed to stand at room temperature for $10 \mathrm{~min}$. The undigested protein was removed by centrifugation and peptides released were assayed. The specific protease activity towards casein was taken as a control. All experiments were done in triplicates.

\section{Determination of Fibrinolytic potential of the protease}

Fibrinolytic activity was performed according to the method of Najafi et al., 2005. A clean piece of pure white cotton cloth was soaked in animal blood (0.1ml) for $15 \mathrm{~min}$ and then allowed to dry at $80^{\circ} \mathrm{C}$ for $5 \mathrm{~min}$ in hot air oven. Then, the cloth pieces were soaked in $2 \%(\mathrm{v} / \mathrm{v})$ formaldehyde for $30 \mathrm{~min}$ and rinsed with water to remove excess formaldehyde. The dried cloth was cut into equal sizes and incubated with crude enzyme $(2 \mathrm{ml})$ at $37^{\circ} \mathrm{C}$ for different incubation periods $(10,20,30,40$ and 50 $\mathrm{min})$. After a given incubation, the cloth was rinsed with tap water for $2 \mathrm{~min}$ without scrubbing and then dried in open air. Visual examination of various pieces exhibited the effect of enzyme in removal of strains. The same procedure was done with the control without the enzyme exposure.

\section{Results and Discussion}

The most significant characteristics of isolate KLG 55 were analyzed (table.1). The isolate grew well on the media. The colony surface was rough, white in colour rod shape, size in the range of $0.8-1.0 \mu \mathrm{m}$. Isolate is gram positive. The isolate indicated negative result for indole test, citrate utilization test, $\mathrm{H}_{2} \mathrm{~S}$ production test, gelatine hydrolysis test. It could extensively hydrolyse starch and casein. It showed positive result for nitrate reduction, oxidation, methyl red test, voges proskauer test, arginine dihydrolase and esculin hydrolysis test. It exhibited good growth at $37^{\circ} \mathrm{C}$. It could tolerate the $\mathrm{pH}$ levels between 5.0 and 9.0. It could not grow above $4 \% \mathrm{NaCl}$ level. It exhibited good growth on fructose, moderate growth on dextrose, sucrose and poor growth on maltose. It could not utilize rhamnose and mannose. 
Isolate KLG 55 indicated good growth with L-asparagine, moderate growth with Serine and Histidine, poor growth with Arginine and Cysteine and no growth for the sources like Valine, phenyl alamine, threonine, hydroxyl praline, methionine as it could not utilize it.

Isolate KLG 55 was sensitive to Rifampin, Chloramphenicol, Erythromycin, Ciprofloxacin, Streptomycin and Gentamicin and it is resistant towards the antibiotic Lincocin.

Based on the results obtained, characteristics of isolate KLG 55 obtained from the soil sample designated as GUG -VI was in close comparison with the strains of Bacillus cereus ( table. 1). Isolate KLG 55 and strains of Bacillus cereus have the following similarities: Colour of the colony, utilization of Dextrose, non-utilization of rhamnose and sensitivity to rifampin and chloramphenicol.

But however, some qualitative and quantitative differences could be noticed. Isolate GD55 did not grow on mannose, where as the reference culture could utilize them. Reference culture utilized gelatin and isolate KLG 55 culture could not. In view of the general close agreement and more similarities and a few differences, isolate KLG 55 can be considered to be as a new strain of Bacillus cereus. Hence, it is designated as Bacillus cereus KLG 55.

\section{Purification of Fibrinolytic Protease from Bacillus cereus KLG 55}

Fermentation broth containing the crude enzyme was subjected to three step procedure involving ammonium sulphate precipitation, Sephadex G-50 gel permeation chromatography and DEAE Sephadex A-50 anion exchange chromatography.

\section{Gel Filtration Chromatography on Sephadex G-50}

The crude broth obtained after fermentation was subjected to ammonium sulphate precipitation at $70 \%$. The pellet so obtained was resuspended in cold saline $(2 \mathrm{ml})$ and dialysed. The dialysed enzyme was first loaded on to a column of Sephadex G-50 and then to a column containing DEAE Sephadex A-50, both the columns were equilibrated with $10 \mathrm{mM}$ Tris-HCL buffer, $\mathrm{pH}$ 8. The column was eluted at a flow rate of $1 \mathrm{ml} / 6 \mathrm{~min}$. The elution profile of gel filtration chromatography is shown in the (Fig.1). The fractions collected were determined for its total protein concentration and fibrinolytic enzyme activity.

The summary of purification steps involved for fibrinolytic protease is presented in the Table.2.

\section{Sodium Dodecyl Sulfatepolyacrylamide Gel Electrophoresis (SDS-PAGE)}

The crude broth, precipitate obtained after ammonium sulphate precipitate and the purified fibrinolytic protease along with standard molecular weight markers were run on SDS-PAGE. The molecular weight of the fibrinolytic protease was determined by comparison of the migration distances of standard marker proteins (Bio-Rad). The molecular weight was determined by interpolation from a linear semi-logarithmic plot of relative molecular mass versus the $R_{f}$ value (relative mobility). Depending on the relative mobility, the molecular weight of fibrinolytic protease enzyme is $31 \mathrm{kDa}$.

\section{Characterization of purified enzyme}

\section{Determination of optimum $\mathrm{pH}$ and $\mathrm{pH}$ stability}

For obtaining the optimum $\mathrm{pH}$ level, different buffers were used such as $10 \mathrm{mM}$ citric acid buffer, $0.05 \mathrm{M}$ sodium phosphate 
buffer, $0.05 \mathrm{M}$ Tris- $\mathrm{HCl}, 0.05 \mathrm{M}$ glycine$\mathrm{NaOH}, 0.1 \mathrm{M}$ sodium phosphate buffer and $0.05 \mathrm{M}$ hydroxyl-chlorite buffer were used.

The results are shown in Fig. 4. It showed optimum $\mathrm{pH}$ of purified enzyme is 8 and stable in the $\mathrm{pH}$ range of 6.5-8.0 between 2 to $20 \mathrm{~h}$.

Table.1 Comparison of characterization of the isolate GD55 and Bacillus cereus

\begin{tabular}{|c|c|c|}
\hline Characteristics & Isolate GD55 & Bacillus Cereus \\
\hline \multicolumn{3}{|l|}{ Colony morphology } \\
\hline Colour of isolate & White & White \\
\hline Spores & Ellipsoidal & Ellipsoidal \\
\hline Configuration & Circular & Circular \\
\hline Margin & Irregular & Irregular \\
\hline Elevation & Flat & Flat \\
\hline Surface & Rough & Rough \\
\hline \multicolumn{3}{|l|}{ Carbon source utilization } \\
\hline Dextrose & $+\mathrm{ve}$ & $+\mathrm{ve}$ \\
\hline Fructose & $+\mathrm{ve}$ & $+\mathrm{ve}$ \\
\hline Sucrose & $+\mathrm{ve}$ & $+\mathrm{ve}$ \\
\hline Rhamnose & $-\mathrm{ve}$ & $-\mathrm{ve}$ \\
\hline Maltose & $+\mathrm{ve}$ & $+\mathrm{ve}$ \\
\hline Mannose & $-\mathrm{ve}$ & $-\mathrm{ve}$ \\
\hline Starch hydrolysis & $+\mathrm{ve}$ & $+\mathrm{ve}$ \\
\hline Casein hydrolysis & $+\mathrm{ve}$ & $+\mathrm{ve}$ \\
\hline Gelatin hydrolysis & $-\mathrm{ve}$ & $-\mathrm{ve}$ \\
\hline Growth at $37^{\circ} \mathrm{C}$ & $+\mathrm{ve}$ & $+\mathrm{ve}$ \\
\hline Growth on $4 \% \mathrm{NaCl}$ & $+\mathrm{ve}$ & $+\mathrm{ve}$ \\
\hline \multicolumn{3}{|l|}{ Sensitivity in } \\
\hline Lincocin $(30 \mu \mathrm{g})$ & $-\mathrm{ve}$ & $-\mathrm{ve}$ \\
\hline Rifampin $(10 \mu \mathrm{g})$ & $+\mathrm{ve}$ & $+\mathrm{ve}$ \\
\hline Chloramphenicol $(20 \mu \mathrm{g})$ & $+\mathrm{ve}$ & $+\mathrm{ve}$ \\
\hline Erythromycin $(30 \mu \mathrm{g})$ & $+\mathrm{ve}$ & $+\mathrm{ve}$ \\
\hline Ciprofloxacin $(10 \mu \mathrm{g})$ & $+\mathrm{ve}$ & $+\mathrm{ve}$ \\
\hline Streptomycin $(30 \mu \mathrm{g})$ & $+\mathrm{ve}$ & $+\mathrm{ve}$ \\
\hline Gentamycin $(10 \mu \mathrm{g})$ & $+\mathrm{ve}$ & $+\mathrm{ve}$ \\
\hline
\end{tabular}


Table.2 Summary of the purification of Fibrinolytic Protease from Bacillus cereus KLG 55

\begin{tabular}{|l|c|c|c|c|c|}
\hline \multicolumn{1}{|c|}{ Prification Step } & $\begin{array}{c}\text { Total } \\
\text { Protein (mg) }\end{array}$ & $\begin{array}{c}\text { Total } \\
\text { Ativity } \\
\text { (U) }\end{array}$ & $\begin{array}{c}\text { Specific } \\
\text { Activity } \\
\text { U/mg }\end{array}$ & $\begin{array}{c}\text { Fold } \\
\text { Purification }\end{array}$ & $\%$ Yield \\
\hline Crude Extract & 11923 & 14.900 & 1.24 & 1 & 100 \\
\hline $\begin{array}{l}70 \% \text { ammonium sulfate } \\
\text { saturation }\end{array}$ & 8564 & 12.250 & 1.43 & 1.15 & 82.21 \\
\hline Sephadex G-50 & 3623 & 6.900 & 1.90 & 1.53 & 46.30 \\
\hline DEAE-Speakex A-50 & 28 & 1500 & 53.57 & 43.20 & 10.06 \\
\hline
\end{tabular}

Fig.1 Gel filteration chromatography on Sephadex G-50

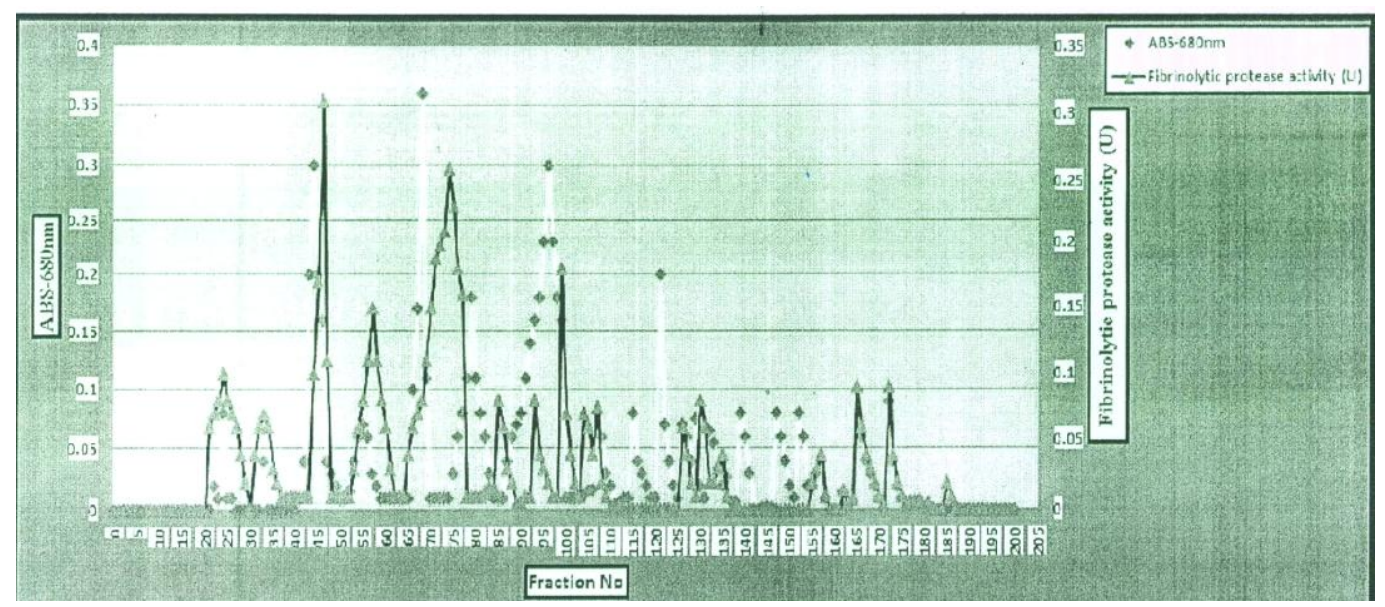

Fig.2 Anion Exchange chromatography on DEAE Sephadex A-50

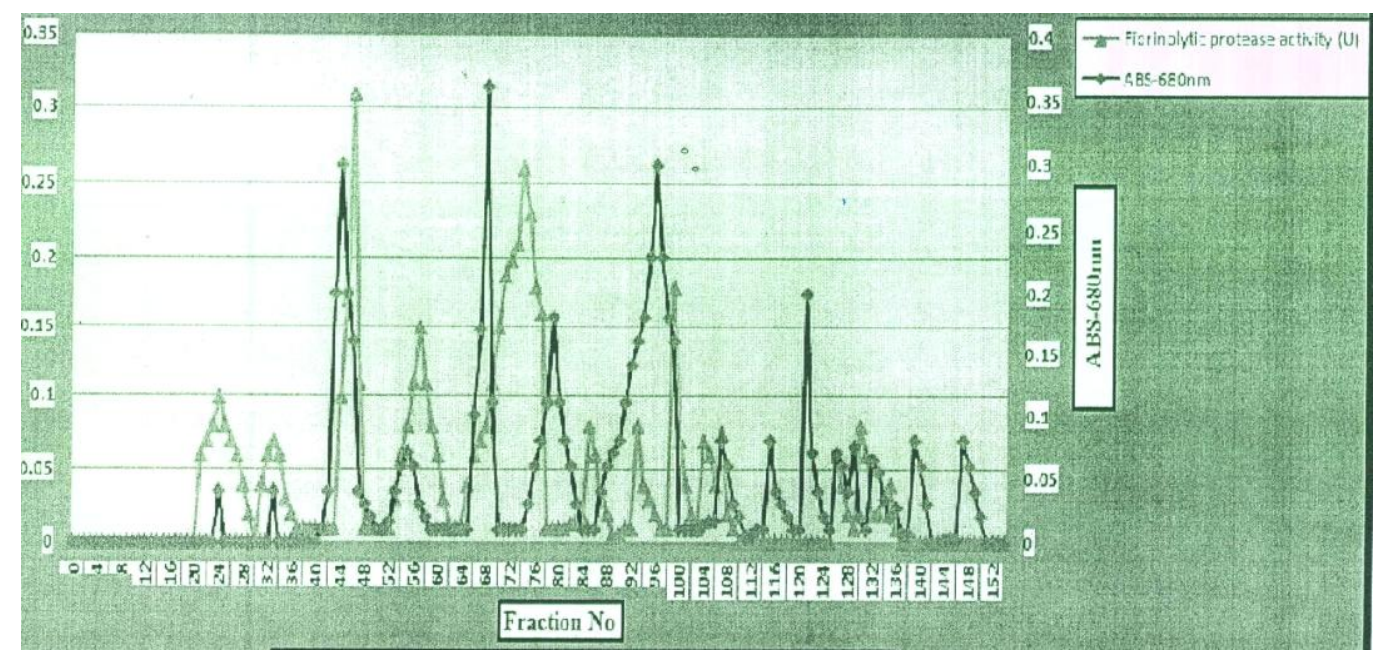


Fig.3 Results obtained from SDS-PAGE run

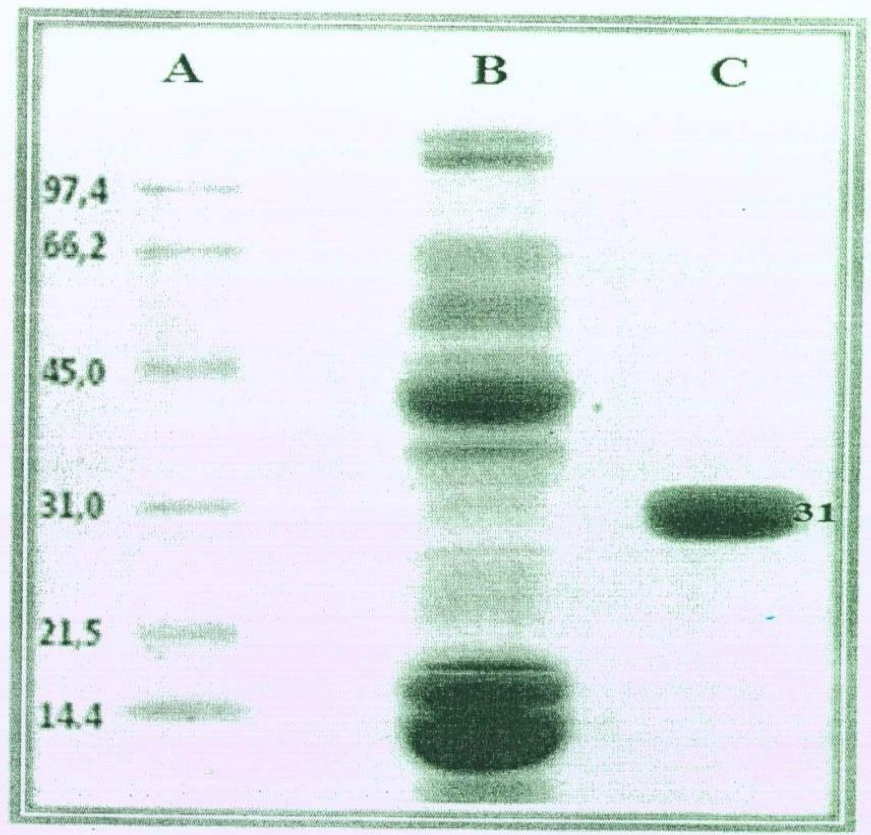

Lane A : Molecular Mass Markers; Lane B: Crude Enzyme; Lane C :Purified Enzyme

Fig.4 Effect of pH on enzyme activity

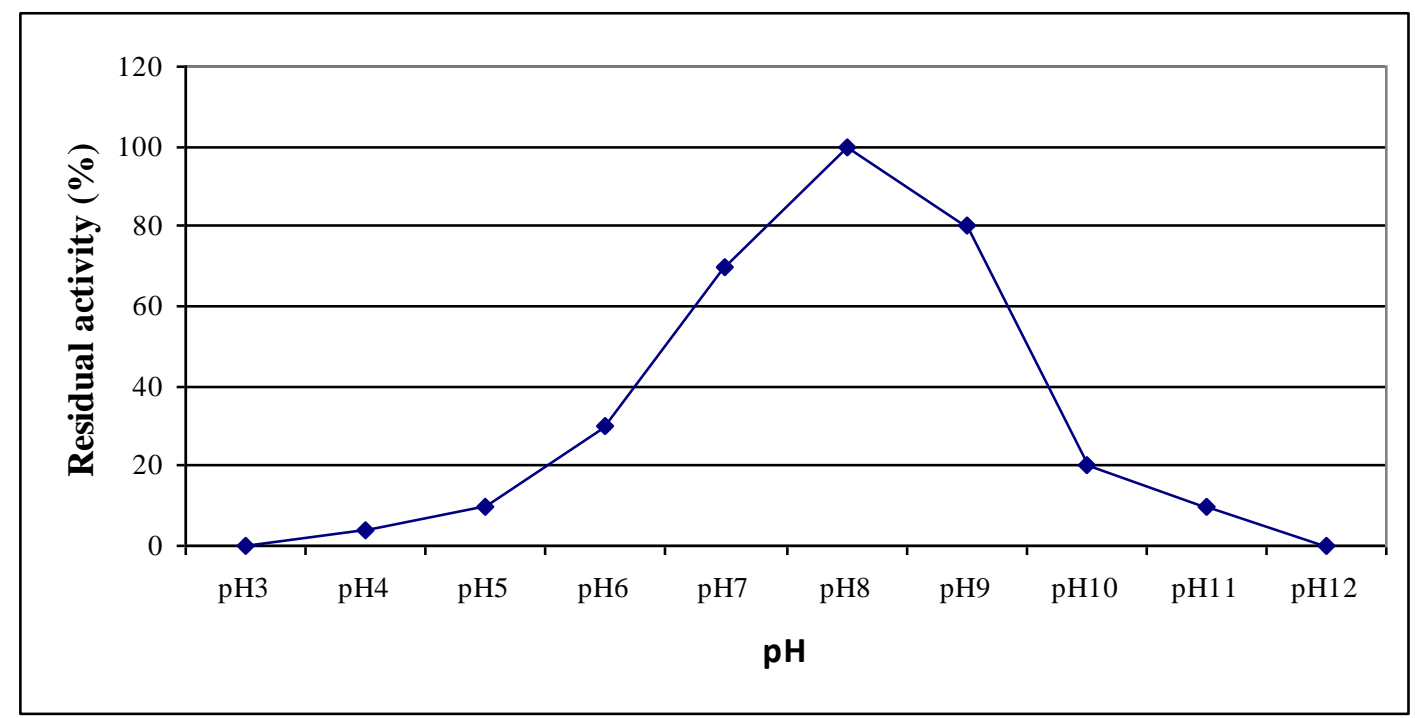


Fig.5 Effect of Temperature on enzyme activity

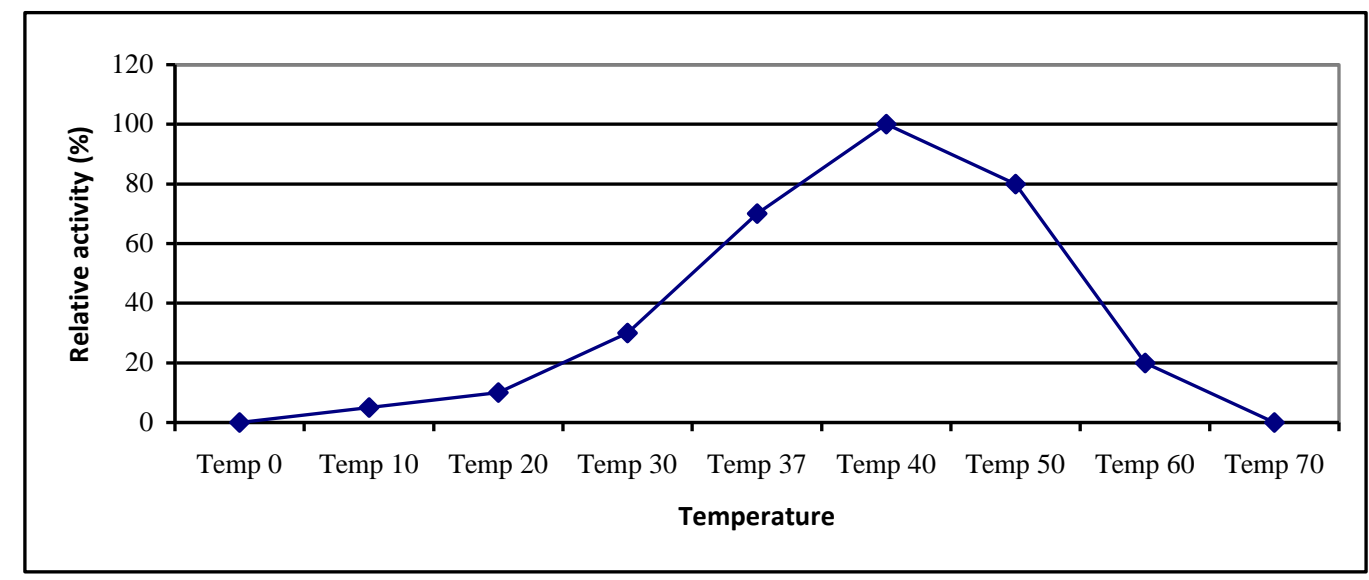

Fig.6 Fibrinolytic proteae activity against different natural substrates

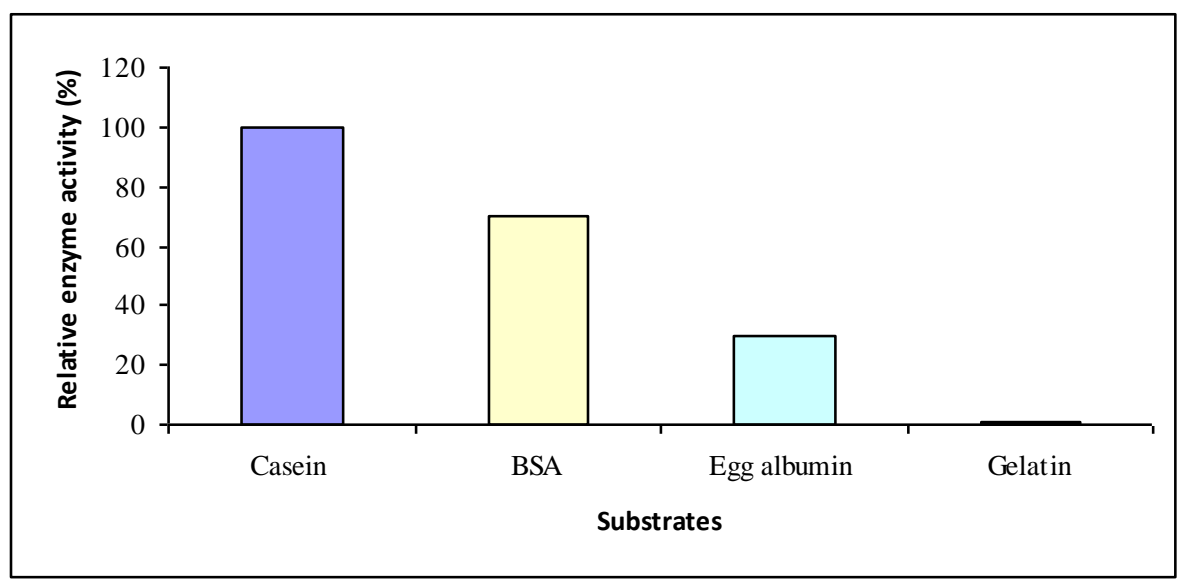

Fig.7 Fibrinolytic potential of the protease

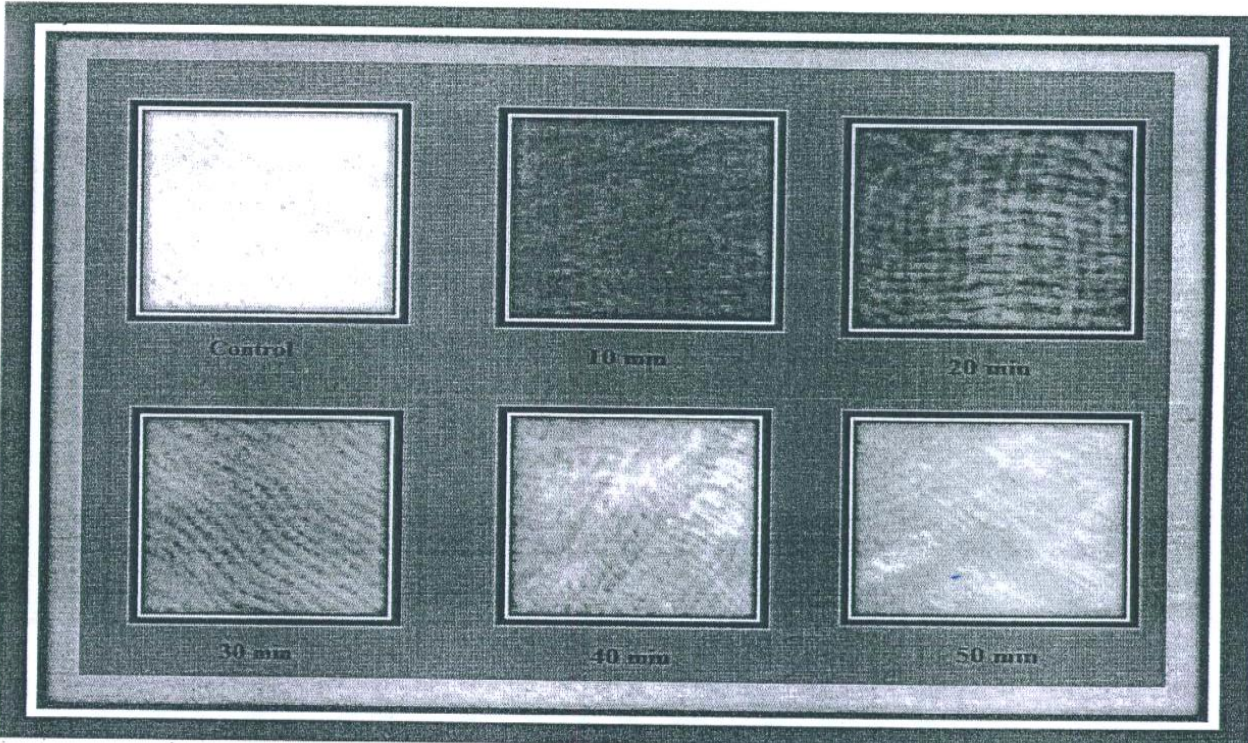




\section{Determination of optimum temperature of purified enzyme}

The activity of the purified enzyme was determined at different temperatures ranging from $10^{\circ} \mathrm{C}-70^{\circ} \mathrm{C}$ for $30 \mathrm{~min}$. The optimum temperature recorded was at $37^{\circ} \mathrm{C}$ and enzyme activity was gradually declined at temperature beyond $40^{\circ} \mathrm{C}$. The results are shown in Fig.5.

\section{Hydrolysis of protein substrates}

When assayed with native proteins as substrates, the protease showed a high level of hydrolytic activity against casein and poor to moderate hydrolysis of BSA and egg albumin, although the hydrolysis was hardly observed with gelatine. The results are presented in the Fig.6.

\section{Fibrinolytic potential of the protease}

The blood strain was removed from a white cotton cloth by incubating the cloth in purified fibrinolytic protease for different time intervals. It was seen that protease produced by Bacillus cereus KLG 55 had high capability of removing the blood strain (50min), which indicates its potential in detergent industries. Anwar et al., (1997) reported the effectiveness of protease on blood strain removal. In the present study the removal of blood strain by Bacillus cereus KLG 55 producing protease enzyme is a promising additive for detergent industry. Vijayalakshmi et al., (2011) reported the removal of blood strain by Bacillus RV.B2.90.

In conclusion, over the last 10 years, several effective thrombolytic agents have been identified and characterized from microorganisms, earthworms, plants, snake venoms, insects and leeches. The thrombolytic agents are of interest as useful tools for understanding fibrinolytic mechanism and as potential therapeutic drugs. Extracellular fibrinolytic proteases produced by Bacillus cereus species are of main interest from a biotechnological perspective, and are not only in scientific fields of protein chemistry and protein engineering but also in applied fields such as foods and pharmaceutical industries. The genus Bacillus contains a number of industrially important species and approximately half of the present commercial production of bulk enzymes derives from the strains of Bacillus cereus.

Microbial enzymes are preferred because they are generally cheaper to produce; their enzyme content is more predictable, controllable, limited space required for their cultivation, and the ease with which they can be genetically manipulated to generate new enzymes with altered properties.

The most significant characteristics of Bacillus cereus KLG 55 are rod shaped, gram-positive microorganism it grew well on the media. The colony surface was rough, white in colour.

However, studies on the production of fibrinolytic proteases from Bacillus cereus remain unexploited.

Different natural substrates collected from various places of Bangalore were screened for the isolation of potent fibrinolytic protease producing Bacillus cereus sp. The isolates formed from the culture samples were tested for their proteolytic activity on milk casein agar medium.. The taxonomic studies were earned out for the selected promising isolate (KLG 55). A close scrunity of the literature indicated that the isolate (KLG 55) was related to Bacillus cereus but different in some biochemical characteristics. In view of some significant 
differences from the reference culture, the isolate was considered to be the novel strains of Bacillus cereus and designated as Bacillus cereus KLG 55.

The isolate (KLG 55) was used for the production of fibrinolytic protease was subjected to purification. The crude enzyme was first purified in a three step procedure involving ammonium sulphate precipitation, Sephadex G-50 gel permeation chromatography and DEAE Sephadex A-50 anion exchange chromatography. The protease was purified 43 fold. The SDSPAGE of the enzyme showed that it has a molecular weight of $31 \mathrm{kDa}$.

\section{References}

Anwar A and Saleemuddin (1997). Alkaline $\mathrm{pH}$ acting digestive enzyme of the polyphagous insect pest Spilosoma oblique: stability and potential as detergent addictives. Biotechnol Appl Biochem. 25: 43-46.

Balaraman K and Prabakaran G (2007). Production and purification of a fibrinolytic enzyme (thrombinase) from Bacillus sphaericus. Ind J Med Res. 126: 459-464.

Buchanan RE and Gibbons NE (1974). Bergey's Manual of Determinative Bacteriology ( $8^{\text {th }}$ ed.). The Williams and Wilkins Co, Baltimore, U.S.A.

Fundagul E, Muharrem $\mathrm{C}$ and Barcin K (2009). Identification of Bacillus species isolated from ropey breads both with classical methods and identification kits. Akdeniz universities iziraat fakultesi dergisi. 22: 201-210.

Gopinath SM, Suneetha TB and Aswini Patil GM (2011). Exploration of newer substrate for fibrinolytic enzyme production by solid state fermentation using Penicillium chrysogenum SGAD 12. J Res Biol. 4: 242-245.
Gopinath SM and Sneha SH (2012). Sessamum oil cake a- novel substrate for Production of fibrinolytic enzymes on solid State fermentation by Penicillium chrysogenumagsfl6. Adv. Pharmacol. Toxicol. 13 (2): 13-17.

Greenberg DM (1957). Plant proteolytic enzymes. Methods in enzymology, ( $2^{\text {nd }}$ edition), Academic press INC. New York USA. 54-64.

Jo H, Deok HA, Lee SJ, Jeong and Kirn JH (2011). Purification and Characterization of a major fibrinolytic enzyme from Bacillus Amyloliquefaciens MJ-41 Isolated from meju. $\mathrm{J}$ of Mic and Biotech. 21(11): 1166-1173.

Laemmli UK (1970). Cleavage of structural proteins during the assembly of the head of bacteriophage T4. Nature. 227: $680-685$.

Lowry OH, Rosebrough NJ and Randall RJ (1951). Protein measurement with the Folin-phenol reagent. J Biol Chem. 193: 265-275.

Mousumi Banerjee, Gopinath B and Thandavarayan Ramamurthy (2011) Phenotypic \& genetic characterization of Bacillus cereus isolated from the acute diarrhoeal patients. Indian J Med Res. 133: 88-95.

Najafi MF and Deobagkar D (2005). Potential application of protease isolated from Pseudomonas aeruginosa PD 100. Ele J Biotechnol. 8: 197-203.

Olajuyigbe FM and Ajele JO (2005). Production of extracellular protease from Bacillus species. Afr $\mathrm{J}$ Biotechnol. 4(8): 776-779.

Peng Y, Huang Q, Zhang, RH and Zhang YZ (2003). Purification and characterization of a fibrinolytic enzyme produced by Bacillus amyloliquefaciens DC-4 screen from douche, a traditional Chinese soybean 
food. Comp Biochem Physiol Biochem Mol Biol. 134: 45-52.

Sneath HAP and Halt GJ (1986). Bergey's manual of systematic bacteriology Vol 2. Baltimore. Williams MD and Wolkins.

Richard RB and Murray PD (2009). Guide to protein purification, Academic Press is an Imprint of Elsevier. 463(2): 14-15.

Vijayalakshmi S, Venkatkumar $\mathrm{S}$ and Thankamani V (2011). Screening of alkalophilic thermophilic protease isolated from Bacillus RV.B2.90 for industrial application. Res Biotechnol. 2(3): 32-41.
Williams ST, Sharpm ME and Holt JG (1989). Bergey's Manual of Systematic Bacteriology Vol. 4. The Williams and Wilkins Co, Tokyo. Willian H (2000). Official methods of analysis international, Association of Offical Analytical Chemists. Washing ton. December-17.

Vyletelova M, Svec P, Pacova Z, Sedlacek I and Roubal P (2002). Occurrence of Bacillus cereus and Bacillus licheniformis strains in the course of UHT milk production. Czech J Anim Sci. 47: 200-205.

\section{How to cite this article:}

Gopinath, S.M., and Lingappa, K. 2016. Identification and Characterization of the Fibrinolytic Enzymes producing Bacterium Strain (Isolate KLG 55) from the Soil Waste. Int.J.Curr.Microbiol.App.Sci. 5(7): 978-989. doi: http://dx.doi.org/10.20546/ijcmas.2016.507.110 